\title{
THE NEOLITHIZATION OF SIBERIA AND THE RUSSIAN FAR EAST: MAJOR SPATIO- TEMPORAL TRENDS (THE 2013 STATE-OF-THE-ART)
}

\author{
Yaroslav V Kuzmin \\ Institute of Geology \& Mineralogy, Siberian Branch of the Russian Academy of Sciences, Novosibirsk 630090, Russia. \\ Email: kuzmin@fulbrightmail.org.
}

\begin{abstract}
The updated chronology of the earliest pottery-containing complexes in Siberia and the Russian Far East is presented herein. The appearance of pottery (i.e. the process of Neolithization) in this vast region of Eurasia is discussed based on a model that represents a simple approximation of calendar ages between key sites as isolines. No clear spatiotemporal patterns for the origin and spread of pottery in northern Asia can be observed because pottery-making (unlike agriculture) could have emerged in different parts of the Old World at various times. Before modeling of pottery dispersal is conducted, careful evaluation of typology and technology of ceramics and stone artifacts should be done, in order to avoid the confusing situation when the results of modeling contradict the basic archaeological information.
\end{abstract}

\section{INTRODUCTION}

The process of Neolithization in the Old World can generally be seen as the emergence of two prehistoric phenomena: (1) pottery and (2) agriculture and stock breeding. While in the Levant and most of western/central Europe the beginning of the Neolithic is usually connected with the appearance of plant cultivation and animal husbandry, in East Asia and northern Eurasia pottery is considered as the primary criterion of the Neolithic (see Kuzmin 2010, 2013a; Kuzmin et al. 2009:892-4). In recent years, particular attention has been given to the process of pottery appearance among the Eurasian hunter-gatherers (e.g. Gronenborn and Petrasch 2010; Hartz et al. 2012). In northern Asia, pottery emerged at the end of the Pleistocene in the hunter-gatherers' continuum (e.g. Kuzmin 2010). This article presents updated information on the Neolithization of Siberia and the Russian Far East compared to the overview by Kuzmin and Orlova (2000), using the sources available up to mid-2013.

\section{MATERIALS AND METHODS}

In order to determine spatiotemporal trends in the spread of pottery throughout Siberia and the Russian Far East, key sites are selected based on data obtained mainly from 2000 to the present (Table 1). A rigorous evaluation of the association between ${ }^{14} \mathrm{C}$ dates and pottery was conducted using the primary publications. Previously, several sites have been related to the Neolithic (and presumably the presence of pottery) based on archaeologists' viewpoints (Kuzmin and Orlova 2000), especially in northeastern Siberia and the Kamchatka Peninsula. However, at several sites (e.g. Koolen' 3, Kukhtui 3, Khurendzha 8, Terkuemkyun 1, Lakhtina 2, Chertov Orvag, and Avacha; see Kuzmin and Orlova 2000), no pottery was found in primary association with the ${ }^{14} \mathrm{C}$-dated charcoal. While it is still possible to call these sites "Neolithic" in terms of general periodization (with some reservations), it would be incorrect to include them in the data set. The present database (Table 1) is purposely not large, because the main task of this analysis is to establish the major features for the age of pottery through the vast territory of northern Eurasia $\left(\sim 14,000,000 \mathrm{~km}^{2}\right.$; see Figure 1).

After the selection of sites, ages were calibrated using the CALIB v 6.1.1 software (see Reimer et al. 2009); the median calendar ages are plotted in Figure 1. Isolines of these values were created with the help of GIS software ArcView 3.3 (Esri Co., Redlands, CA, USA), in the "Module Spatial Analyst" regime by the "Interpolate Surface" command (IDW method), for 14 intervals of 1000 -yr length each $(2000-16,000 \mathrm{cal} \mathrm{BP})$. This is the simplest possible interpolation, without any

Proceedings of the Radiocarbon and Archaeology 7th International Symposium

Ghent, Belgium, April 2013 | Edited by Mark Van Strydonck, Philippe Crombé, and Guy De Mulder

(C) 2014 by the Arizona Board of Regents on behalf of the University of Arizona 


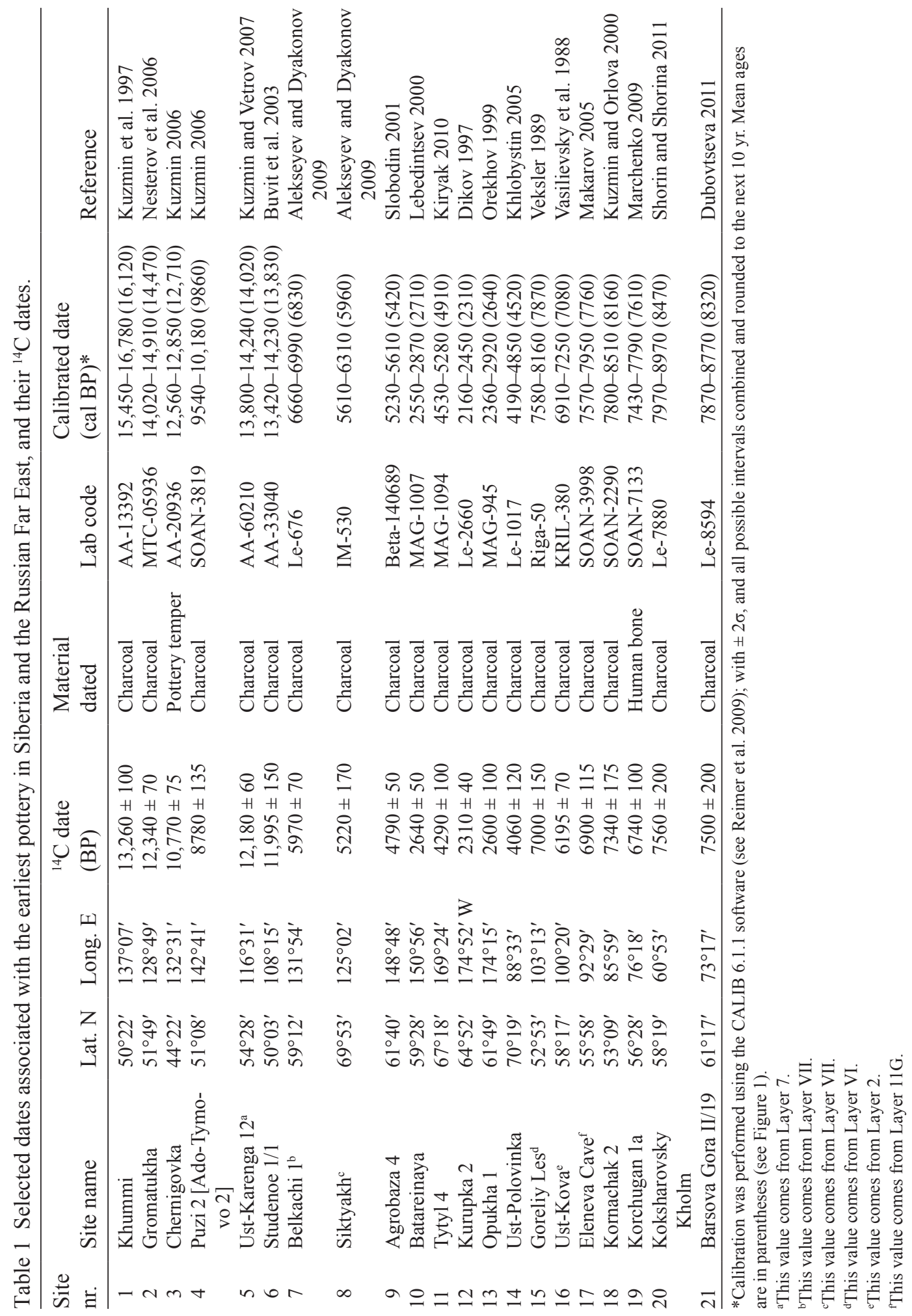




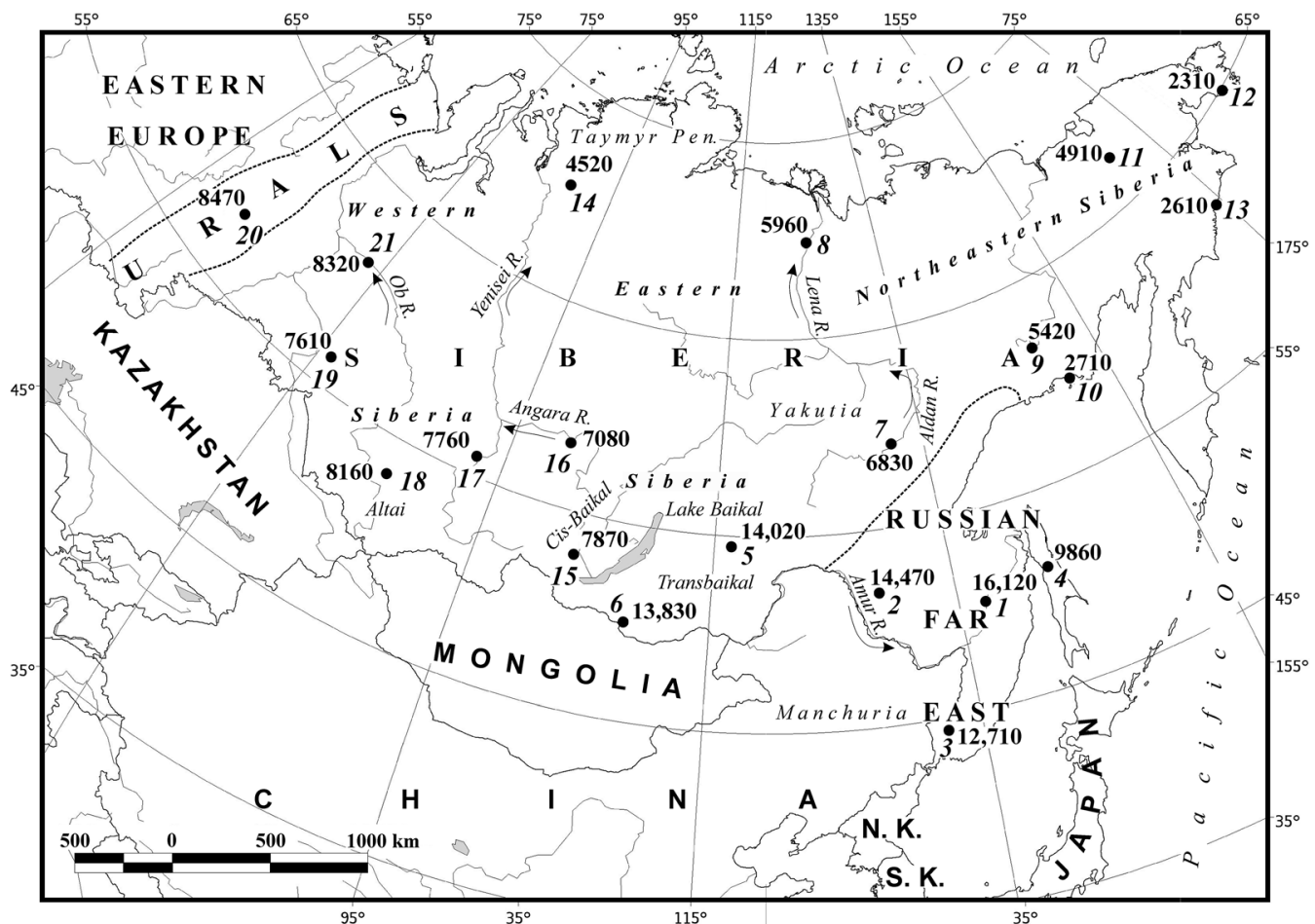

Figure 1 Key sites with the earliest pottery (indicated by black circles, with median ages in cal BP; see Table 1) and main geographic regions in Siberia and the Russian Far East. N.K. - North Korea; S.K. - South Korea. Site numbers (in bold italics) correspond to those in Table 1.

corrections for absence of data in neighboring regions. Although this information exists (see below), it was not entered into the database in order to see which "predicted" values will be generated after this formal attempt to produce ages based on limited knowledge.

\section{RESULTS AND DISCUSSION}

In Figure 2, isolines for the ages of the oldest appearance of pottery in the region under review are drawn. They do not represent a clear east-west cline as suggested by some scholars (e.g. Dolukhanov and Shukurov 2004). For example, the earliest pottery in the Altai region of western Siberia (Kornachak 2 site, median age of $\sim 8160 \mathrm{cal} \mathrm{BP}$ ) is older than in the neighboring territories east of the Altai, namely in the Yenisei and Angara River basins: Eleneva Cave ( 7760 cal BP) and the Ust-Kova site ( $7080 \mathrm{cal}$ BP), respectively (in Figure 2, see the $8000 \mathrm{cal}$ BP isoline, dashed for this purpose).

The assumption about the origin of pottery in one particular region of Eurasia (i.e. East Asia) and its spread toward the west (i.e. Siberia and eastern Europe) as suggested previously (e.g. Davison et al. 2009) cannot be supported by solid evidence. This is because no reliable information exists about the genetic relationship (i.e. one originates directly from the other) between ceramic complexes. It seems that the region with the earliest pottery in Siberia and the Russian Far East, the Amur River Basin, did not contribute to the spread of ceramics into the neighboring areas. There is no clear similarity between the pottery of the Osipovka (i.e. the Khummi site) and Gromatukha (i.e. the Gromatukha site) cultural complexes (dated to $\sim 16,120-14,470 \mathrm{cal} \mathrm{BP}$ ) and the potsherds from the Ust-Karenga 12 site ( 14,020 cal BP) located west of the Amur River Basin (e.g. Kuzmin and Vetrov 2007:15) (see Figures 1-2). 


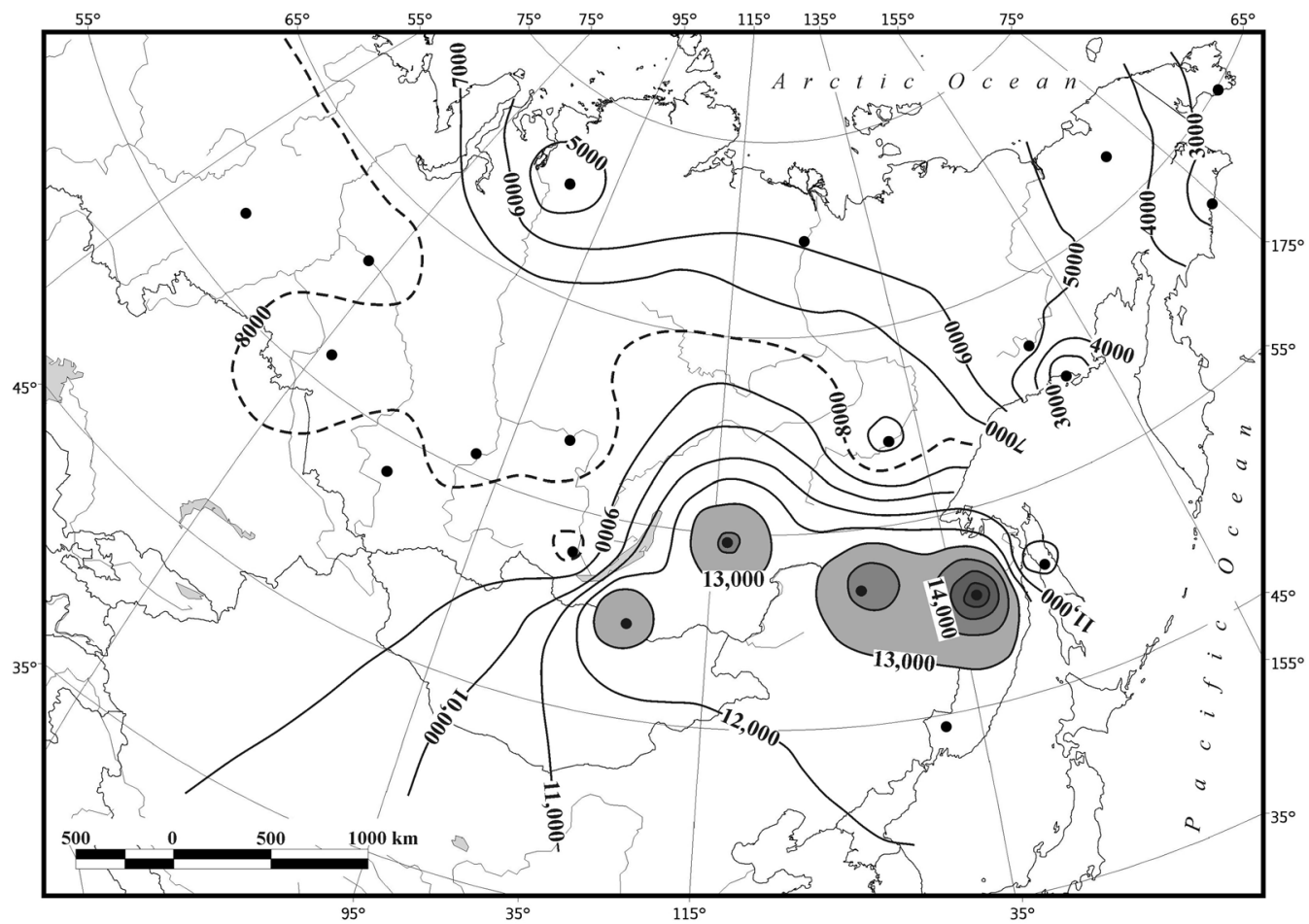

Figure 2 Isolines for the age of the earliest pottery in Siberia and the Russian Far East (in cal BP). Key sites are the same as in Figure 1; the areas with the oldest values are shaded gray.

There are two main centers of pottery dispersal in Siberia in the Holocene (e.g. Kuzmin 2013b): (1) the Cis-Baikal region, from where pottery with a net-impressed design spread to the neighboring regions after $\sim 7900$ cal BP: Yakutia (first appearance at $\sim 6800 \mathrm{cal} \mathrm{BP}$ ), Yenisei River Basin ( $7800 \mathrm{cal} \mathrm{BP}$ ), and part of Transbaikal (after $\sim 7900 \mathrm{cal} \mathrm{BP}$ ) (see also McKenzie 2009); and (2) Aldan River Basin in Yakutia, from where pottery of the Syalakh and Belkachi cultures spread to the north and northeast after $\sim 6000$ cal BP (see also Alekseyev and Dyakonov 2009). This information clearly does not fit with the supposed spread of pottery in northern Eurasia (sensu Dolukhanov and Shukurov 2004).

The "predicted" ages generated in this study by simple interpolation of the Siberian data set to the neighboring regions appear to be unrealistic (see Figure 2): for Mongolia, the predicted age is $\sim 12,000-9000$ cal BP while the existing evidence shows that it should be $\sim 8500-6400$ cal BP (Séfériadès 2004; S A Gladyshev, personal communication, 2013). For Korea and northeast China [Manchuria], predicted values are $\sim 13,000-11,000$ cal BP; however, based on solid data it should be $\sim 7700$ cal BP (Korea; e.g. Cho and Ko 2009) and $~ 8300$ cal BP (Manchuria; Shelach 2006).

In this author's opinion, it is fundamentally wrong to "model" the spread of pottery from a supposed center(s) of origin using the ${ }^{14} \mathrm{C}$ dates. Before doing this, one must show that there is a genetic relationship between the pottery complexes, like in the case of the origin and spread of agriculture from the Levant to western/central Europe (e.g. Gkiasta et al. 2003). For Siberia and the Russian Far East, this is impossible in most cases because pottery-making requires only knowledge of firing and raw material (e.g. Darvill 2002:338), and people were familiar with firing clay since at least 26,000 yr ago (e.g. Vandiver et al. 1989). Therefore, the results of such modeling are practically meaningless from the view of archaeology. However, some scholars still explore this approach for northern Eur- 
asia (e.g. Hartz et al. 2012), and the discussion about its validity is ongoing (see Kuzmin 2013c; Hartz and Piezonka 2013). Undoubtedly, some heuristic models can be used as working hypotheses (e.g. Gronenborn 2009, 2011), but rigorous analysis is required to turn them into solid evidence. Clearly, much work is still needed to understand the patterns of pottery distribution in northern Eurasia.

\section{CONCLUSIONS}

Current knowledge of ${ }^{14} \mathrm{C}$ ages of the early pottery complexes from Siberia and the Russian Far East does not allow to draw any reliable conclusion about the place(s) of pottery origin and spread. According to the available data, the oldest pottery is known from the southern part of the territory, notably the Amur River Basin. The age of the pottery complexes decreases toward the west (via the eastern and western parts of Siberia) and northeast (in the direction of northeastern Siberia). However, no straightforward spatiotemporal trends can be observed. It is incorrect, therefore, to assume that pottery originated in one particular region and then spread to the neighboring territories, as suggested by the hyperdiffusionism paradigm (e.g. Childe 1954; see other examples in Trigger 2006:326-44). An unbiased analysis of the entire data set (including both pottery and stone artifacts) should be carried out in the near future to reveal the details of the Neolithization process in Siberia and the Russian Far East.

\section{ACKNOWLEDGMENTS}

I am grateful to the Organizers of the 7th International Symposium "Radiocarbon and Archaeology" for accepting the monographic session on the Neolithization of Eurasia and my talk; the current paper is based on it. This study is supported by the Russian Foundation for Basic Sciences (RFFI), grants 12-06-00045 and 13-06-00363. Dr Susan G Keates kindly checked the grammar and made some editorial suggestions. I am grateful to two reviewers for their comments and suggestions. All possible mistakes, however, belong to me.

\section{REFERENCES}

Alekseyev AN, Dyakonov VM. 2009. Radiocarbon chronology of Neolithic and Bronze Age cultures in Yakutia. Archaeology, Ethnology \& Anthropology of Eurasia 37(3):26-40.

Buvit I, Waters MR, Konstantinov MV, Konstantinov AV. 2003. Geoarchaeological investigations at Studenoe, an Upper Paleolithic site in the Transbaikal region, Russia. Geoarchaeology 18(6):649-73.

Childe VG. 1954. New Light on the Most Ancient East. 4th edition. New York: F.A. Praeger. 255 p.

Cho D, Ko I. 2009. Hunter-gatherer ceramics of Neolithic Korea. In: Jordan P, Zvelebil M, editors. Ceramics before Farming: The Dispersal of Pottery among Prehistoric Eurasian Hunter-Gatherers. Walnut Creek: Left Coast Press. p 149-66.

Darvill T. 2002. The Concise Oxford Dictionary of Archaeology. Oxford: Oxford University Press. 506 p.

Davison K, Dolukhanov PM, Sarson GR, Shukurov A, Zaitseva GI. 2009. Multiple sources of the European Neolithic: mathematical modelling constrained by radiocarbon dates. Quaternary International 203(1-2):10-8.

Dikov NN. 1997. Asia at the Juncture with America in Antiquity (The Stone Age of the Chukchi Peninsula). Anchorage: Shared Beringian Heritage Program. 248 p.
Dubovtseva EN. 2011. Radiokarbonnye daty s poseleniya Barsova Gora II/19 i Sumpanya III [Radiocarbon dates from the Barsova Gora II/19 and Sumpanya III sites]. In: Chemyakin YP, editor. Voprosy Arkheologii Urala. Vypusk 26. Yekaterinburg: Magellan Press. p 237-8. In Russian.

Dolukhanov P, Shukurov A. 2004. Modelling the Neolithic dispersal in northern Eurasia. Documenta Praehistorica XXXI:35-47.

Gkiasta M, Russel T, Shennan S, Steele J. 2003. Neolithic transition in Europe: the radiocarbon record revisited. Antiquity 77(295):45-62.

Gronenborn D. 2009. Transregional culture contacts and the Neolithization process in northern Central Europe. In: Jordan P, Zvelebil M, editors. Ceramics before Farming: The Dispersal of Pottery among Prehistoric Eurasian Hunter-Gatherers. Walnut Creek: Left Coast Press. p 527-50.

Gronenborn D. 2011. Early pottery in Afroeurasia - origins and possible routes of dispersal. In: Hartz S, Lüth F, Terberger T, editors. Early Pottery in the Baltic - Dating, Origin and Social Context. Mainz: Philipp von Zabern Verlag. p 59-80.

Gronenborn D, Petrasch J, editors. 2010. The Spread of the Neolithic in Central Europe. Mainz: Verlag des Römisch-Germanischen Zentralmuseums. 643 p. 
Hartz S, Piezonka H. 2013. North Eurasian hunter-gatherer ceramics as an archaeological source: reply to Kuzmin (2013). Radiocarbon 55(1):205-9.

Hartz S, Kostyleva E, Piezonka H, Terberger T, Tsydenova N, Zhilin MG. 2012. Hunter-gatherer pottery and charred residue dating: new results on early ceramics in the north Eurasian forest zone. Radiocarbon 54(3-4):1033-48.

Kiryak (Dikova) MA. 2010. The Stone Age of Chukotka, Northeastern Siberia (New Materials). Oxford: Archaeopress. 270 p.

Khlobystin LP. 2005. Taymyr: The Archaeology of Northernmost Eurasia. Washington, DC: Smithsonian Institution. $235 \mathrm{p}$.

Kuzmin YV. 2006. Palaeoenvironment and chronology. In: Nelson SM, Derevianko AP, Kuzmin YV, Bland RL, editors. Archaeology of the Russian Far East: Essays in Stone Age Prehistory. Oxford: Archaeopress. p 13-40.

Kuzmin YV. 2010. The Neolithic of the Russian Far East and neighbouring East Asia: definition, chronology, and origins. Bulletin of the Indo-Pacific Prehistory Association 30:157-62.

Kuzmin YV. 2013a. Two trajectories in the Neolithization of Eurasia: pottery versus agriculture (spatiotemporal patterns). Radiocarbon 55(2-3):1304-13.

Kuzmin YV. 2013b. Northern and northeastern Asia: archaeology. In: Bellwood PS, editor. The Encyclopedia of Global Human Migration. Volume 1. Prehistory. Oxford: Blackwell. p 191-6.

Kuzmin YV. 2013c. The patterns of Neolithization in the north Eurasian forest zone: a comment on Hartz et al. (2012). Radiocarbon 55(1):201-3.

Kuzmin YV, Orlova LA. 2000. The Neolithization of Siberia and the Russian Far East: radiocarbon evidence. Antiquity 74(284):356-65.

Kuzmin YV, Vetrov VM. 2007. The earliest Neolithic complex in Siberia: the Ust-Karenga 12 site and its significance for the Neolithisation process in Eurasia. Documenta Praehistorica XXXIV:9-20.

Kuzmin YV, Jull AJT, Lapshina ZS, Medvedev VE. 1997. Radiocarbon AMS dating of the ancient sites with earliest pottery from the Russian Far East. $\mathrm{Nu}$ clear Instruments and Methods in Physics Research B 123(1-4):496-7.

Kuzmin YV, Jull AJT, Burr GS. 2009. Major patterns in the Neolithic chronology of East Asia: issues of the origin of pottery, agriculture, and civilization. $R a$ diocarbon 51(3):891-903.

Lebedintsev AI. 2000. Early Maritime Cultures of Northwestern Priokhot'e. Anchorage: Shared Beringian Heritage Program. 288 p.

Marchenko ZV. 2009. Radiouglerodnaya khronologiya arkheologicheskikh pamyatnikov epokhi neolita rannego metalla Barabinskoi lesostepi [Radiocarbon chronology of archaeological sites of the Neolithic and Early Metal ages in the Baraba forest steppe] In: Kiryushin YF, Tishkin AA, editors. Rol Estestvenno-Nauchnykh Metodov $v$ Arkheologicheskikh Issledovaniyakh. Barnaul: Altai State University Press. p 140-3. In Russian.
Makarov NP. 2005. Chronology and periodization of the Neolithic and Bronze Age of the Krasnoyarsk forest steppe. In: Kharinsky AV, editor. Izvestiya Laboratorii Drevnikh Technologyi. Vypusk 3. Irkutsk: Irkutsk State Technical University. p 149-71. In Russian with English abstract.

McKenzie HG. 2009. Review of early hunter-gatherer pottery in Eastern Siberia. In: Jordan P, Zvelebil M, editors. Ceramics before Farming: The Dispersal of Pottery among Prehistoric Eurasian Hunter-Gatherers. Walnut Creek: Left Coast Press. p 167-208.

Nesterov SP, Sakamoto M, Imamura M, Kuzmin YV. 2006. The Late-Glacial Neolithic complex of the Gromatukha site, Russian Far East: new results and interpretations. Current Research in the Pleistocene 23:46-9.

Orekhov AA. 1999. An Early Culture of the Northwest Bering Sea. Anchorage: Shared Beringian Heritage Program. $216 \mathrm{p}$.

Reimer PJ, Baillie MGL, Bard E, Bayliss A, Beck JW, Blackwell PG, Bronk Ramsey C, Buck CE, Burr GS, Edwards RL, Friedrich M, Grootes PM, Guilderson TP, Hajdas I, Heaton TJ, Hogg AG, Hughen KA, Kaiser KF, Kromer B, McCormac FG, Manning SW, Reimer RW, Richards DA, Southon JR, Talamo S, Turney CSM, van der Plicht J, Weyhenmeyer CE. 2009. IntCal09 and Marine09 radiocarbon age calibration curves, 050,000 years cal BP. Radiocarbon 51(4):1111-50

Séfériadès ML. 2004. An aspect of Neolithisation in Mongolia: the Mesolithic-Neolithic site of Tamsagbulag (Dornod district). Documenta Praehistorica XXXI:139-49.

Shelach G. 2006. Economic adaptation, community structure, and sharing strategies of households at early sedentary communities in northeast China. Journal of Anthropological Archaeology 25(3):318-45.

Shorin AF, Shorina AA. 2011. Radiokarbonnye daty Koksharovskogo kholma [Radiocarbon dates from the Koksharovo knoll]. In: Chemyakin YP, editor. Voprosy Arkheologii Urala. Vypusk 26. Yekaterinburg Magellan Press. p 249-54. In Russian.

Slobodin SB. 2001. Verkhnaya Kolyma i Kontinentalnoe Priokhotye $v$ Epokhu Neolita $i$ Rannego Metalla [The Upper Kolyma River Basin and Inland Okhotsk Sea Region in the Neolithic and Early Metal Epochs]. Magadan: Severo-Vostochny Kompleksny Nauchno-Issledovatelsky Institut. 202 p. In Russian.

Trigger BG. 2006. A History of Archaeological Thought. 2nd edition. Cambridge: Cambridge University Press. 710 p.

Vandiver PB, Soffer O, Klíma B, Svoboda J. 1989. The origins of ceramic technology at Dolní Věstonice, Czechoslovakia. Science 246(4933):1002-8.

Vasilievsky RS, Burilov VV, Drozdov NI. 1988. Arkheologicheskie Pamyuatniki Severnogo Priangarya [Archaeological Sites of the Northern Angara River Basin]. Novosibirsk: Nauka Publishers. 224 p. In Russian.

Veksler VS. 1989. Radiocarbon dates of Riga II. Radiocarbon 31(1):47-54. 